\title{
Composition and dynamics of particle-associated and free-living bacterial communities in the Weser estuary, Germany
}

\author{
Natascha Selje, Meinhard Simon*
}

Institute for Chemistry and Biology of the Marine Environment, University of Oldenburg, PO Box 2503, 26111 Oldenburg, Germany

\begin{abstract}
We studied the spatio-temporal dynamics and community composition of the free-living and particle-associated bacterial community in the salinity gradient of the Weser estuary, Germany, between March and December 1999 and in May 2000. Bacterial numbers covaried with temperature and those of the particle-associated fraction with the turbidity, exhibiting highest proportions in the turbidity maximum between July and December. The analysis of the composition of the particle-associated bacterial community by fluorescence in situ hybridization (FISH) with group-specific oligonucleotide probes showed that Cytophaga/Flavobacteria (CF) comprised the highest proportions in the freshwater section (mean: $28 \pm 8.9 \%$ of DAPI cell counts) and decreased towards the marine section to $14.0 \pm 3.7 \%, \alpha-, \beta$ - and $\gamma$-Proteobacteria constituted around $10 \%$ without pronounced variations among the various sections. The community analysis based on PCR-amplified fragments of the $16 \mathrm{~S}$ rRNA gene, along with denaturing gradient gel electrophoresis (DGGE) and a cluster analysis of the banding patterns, exhibited pronounced differences along the salinity gradient and well-separated communities within the freshwater, brackish and marine sections. Seasonal differences within the separate communities and between the particle-associated and free-living bacterial communities were less pronounced. The sequence analysis of prominent bands revealed that the communities consisted of bacteria affiliated to Proteobacteria, CF and Actinobacteria. Clones of the CF cluster were rather distantly related to phylotypes from other aquatic environments, whereas clones related to Actinobacteria clustered closely together with phylotypes from other aquatic systems. Clones belonging to $\alpha$ - and $\beta$-Proteobacteria also affiliated closely to phylotypes from other aquatic systems but more closely to isolated strains than the CF and Actinobacteria clones.
\end{abstract}

KEY WORDS: Bacteria · DGGE · Cluster analysis · 16S rDNA sequences · Fluorescence in situ hybridization · Estuaries · Turbidity maximum

Resale or republication not permitted without written consent of the publisher

\section{INTRODUCTION}

Estuaries are highly productive and dynamic ecosystems with a pronounced salinity gradient which affects the distribution of pelagic as well as benthic communities of eukaryotic and in particular, higher organisms. These ecosystems are also characterized by a high load of suspended matter (SPM) which, due to the hydrodynamic properties, accumulates in a typical turbidity maximum (TM) area at salinities of 2 to $5 \%$ (Nybakken

${ }^{*}$ Corresponding author. Email: m.simon@icbm.de
2001). Estuaries are usually net-heterotrophic and exhibit very high rates of heterotrophic bacterial activity because of the high load of particulate and dissolved organic matter (Findlay et al. 1991, Goosen et al. 1997). Often, particle-associated bacteria dominate bacterial processes (Bell \& Albright 1981, Bent \& Goulder 1981, Schuchardt \& Busch 1991, Crump et al. 1998).

At salinities of 5 to $7 \%$ o the estuarine eukaryotic biota exhibits its lowest diversity, presumably because of the highly fluctuating environmental conditions and osmotic constraints of freshwater and marine organisms. However, typical eukaryotic communities do 
exist in estuaries consisting of organisms with a wider salt tolerance than most other marine and freshwater biota (Nybakken 2001). Whether typical prokaryotic estuarine communities also exist is basically unknown, mainly because there have been fewer studies of the composition of estuarine bacterial communities than of freshwater and marine bacterial communities, which are quite different. Certain clusters within the $\alpha$ - and $\beta$-subclass Proteobacteria are typical for freshwater environments but are basically absent in marine environments where other bacterial groups typically prosper (Rheinheimer 1991, Zwart et al. 1998, Glöckner et al. 1999, 2000, Giovannoni \& Rappé 2000, Rappé et al. 2000). There are some indications of a distinct estuarine bacterial community from the Columbia River estuary, which consists of selected freshwater and marine components (Crump et al. 1999). There is also recent evidence that estuarine bacterial communities undergo a strong physiological stress at changing salinities, leading to reduced bacterial production and enhanced respiration (del Giorgio \& Bouvier 2002).

The composition of bacterial communities has been studied in a limited number of estuaries: the Chesapeake Bay (Bidle \& Fletcher 1995) and 2 of its tributaries (Bouvier \& del Giorgio 2002); the Columbia River estuary (Crump et al. 1999); and the San Francisco Bay (Hollibaugh et al. 2000). The study in the Chesapeake Bay was based on 5S rRNA profiles, that of the Columbia River estuary on clone libraries of 16S rRNA genes and that in Chesapeake Bay's tributaries on fluorescence in situ hybridization (FISH) with group-specific oligonucleotide probes. The San Francisco Bay study used denaturing gradient gel electrophoresis (DGGE) of PCR-amplified 16S rRNA gene fragments. These studies provide some information on the composition and seasonal variations of estuarine bacterial communities. For a better understanding of the bacterial processing of the organic matter load in these highly productive ecosystems at the interface between the freshwater and marine realms, we need much more detailed insights into the spatio-temporal dynamics of the composition of particle-associated and free-living bacterial communities as well as the phylogenetic affiliation of their most prominent members.

In this study, we examined the composition of the particle-associated and free-living bacterial communities in the salinity gradient of the Weser estuary, Germany, using FISH with group-specific oligonucleotide probes, by DGGE and by sequencing selected bands from PCR-amplified 16S rRNA gene fragments. Previous investigations within the same estuary have shown that proportions of particle-associated bacteria range between 20 and $75 \%$ of total bacterial numbers (Schuchardt \& Busch 1991, Schuchardt \& Schirmer 1991a).

\section{MATERIALS AND METHODS}

Study site and sampling. The estuary of the river Weser extends between the city of Bremen $(<0.5 \%$ salinity, $<2 \mathrm{mS} \mathrm{cm}^{-1}, 53.1^{\circ} \mathrm{N}, 8.5^{\circ} \mathrm{E}$ ) and beyond Bremerhaven (28\% salinity, $>30 \mathrm{mS} \mathrm{cm}^{-1}$ ) over $80 \mathrm{~km}$ (Fig. 1) with a pronounced TM between $\mathrm{km} 40$ and 60 ( 2 to $5 \%$ salinity). The annual discharge ranges from 250 to $360 \mathrm{~m}^{3} \mathrm{~s}^{-1}$ (mean $317 \mathrm{~m}^{3} \mathrm{~s}^{-1}$ ) and the mean tidal range is $4.1 \mathrm{~m}$ (Engel 1995). Upstream of the weakly stratified marine section the estuary is well mixed due to high current velocities (Grabemann \& Krause 1989). Samples were collected monthly between March and December 1999 and additionally in May 2000 on board RV 'Bakensand' by a low pressure pump from a depth of $1 \mathrm{~m}$ during the outflowing tide

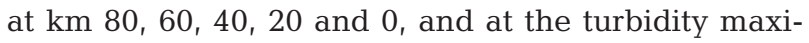
mum (TM; Fig. 1). Temperature, conductivity, pH, oxygen and turbidity were recorded continuously with in situ sensors (WTW, Digi, Monitex). Chlorophyll a (chl a) was determined spectrophotometrically after hot ethanol extraction.

Bacterial cell counts. On board, $2 \mathrm{ml}$ of sample were filtered onto a $5 \mu \mathrm{m}$ Nuclepore filter (25 mm diameter) to collect particle-associated bacteria. From this filtrate, $1 \mathrm{ml}$ was subsequently filtered through a $0.2 \mu \mathrm{m}$ Nuclepore filter (25 mm diameter) to collect free-living bacteria. Samples were prepared in triplicates and stored at $-20^{\circ} \mathrm{C}$ until further processing. Cell numbers were determined by epifluorescence microscopy, using a simultaneous DAPI/acridine orange counterstaining method (Crump et al. 1998) to prevent nonspecific staining of particulate material by DAPI. At least 10 randomly chosen view fields and a minimum of 1000 cells were enumerated under a microscope (Zeiss Axioskop) at a magnification of $1250 \times$.

FISH analysis. Filters for particle-associated and free-living bacteria were prepared on board in the same way as for bacterial cell counts and kept frozen until fixation within $24 \mathrm{~h}$. Samples were fixed for 60 min with a freshly prepared $4 \%$ paraformaldehyde solution, rinsed with $1 \mathrm{ml}$ of phosphate buffer saline (pH 7.2) and with $1 \mathrm{ml}$ Seralpure ${ }^{\circledR}$ water. After dehydration in solutions of 50,80 and $100 \%$ ethanol, filters were frozen at $-20^{\circ} \mathrm{C}$ until hybridization. FISH with rRNA-targeted oligonucleotide probes of triplicate subsamples was performed as described in Glöckner et al. (1996). Filters were cut into thirds, placed on glass slides and hybridized for $5 \mathrm{~h}$ at $46^{\circ} \mathrm{C}$. The following oligonucleotide probes linked to Cy3 (Molecular Probes ${ }^{\circledR}$ ) were applied: EUB338, specific for the domain Bacteria (Amann et al. 1990), ALF1b, BET42a, GAM42a $(\alpha-, \beta$ - and $\gamma$-Proteobacteria, Manz et al. 1992) and CF319a (bacteria of the Cytophagal Flavobacteria cluster, Manz et al. 1996). Hybridization 


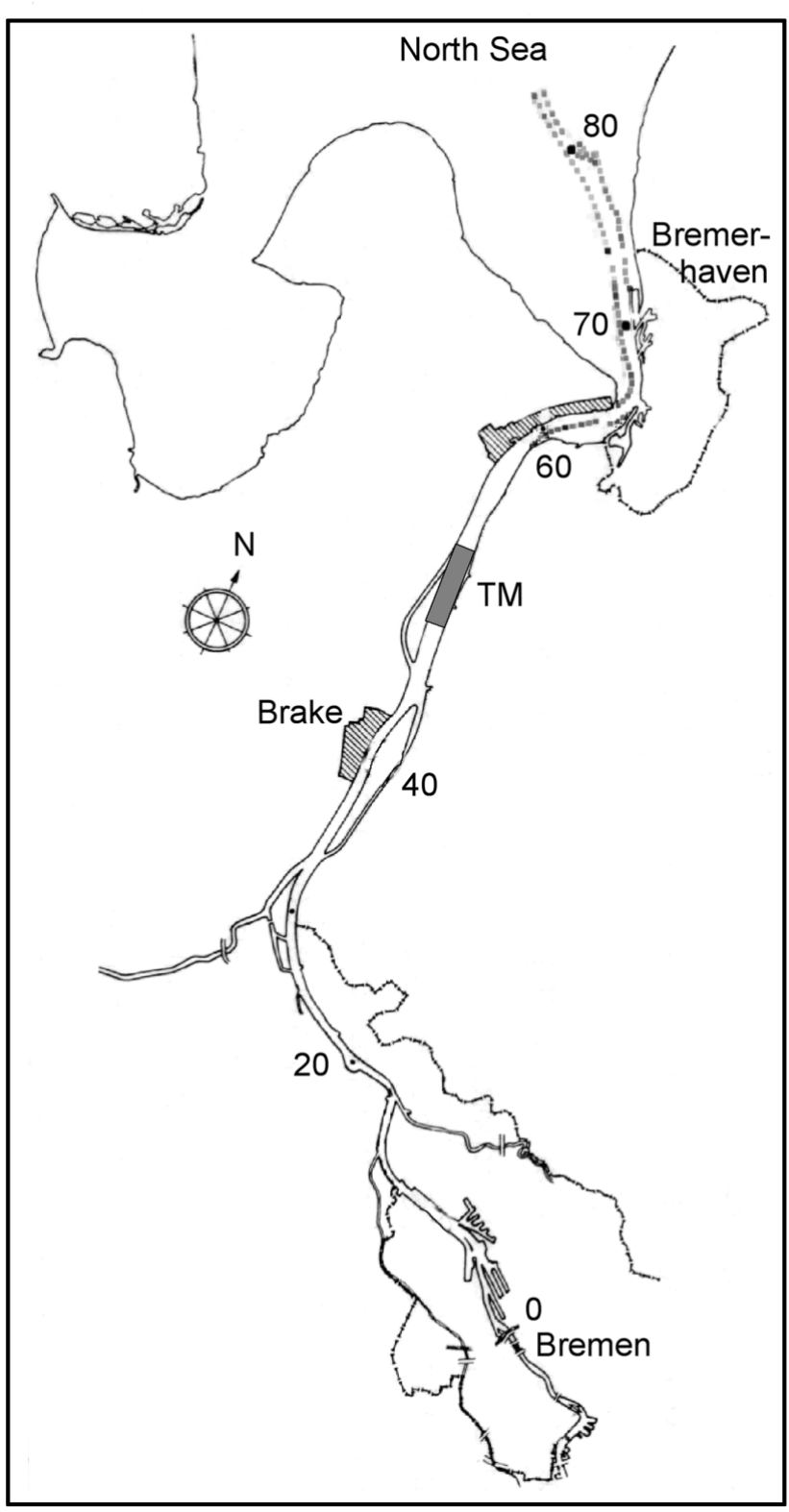

Fig. 1. The Weser estuary, Germany, with the sampling locations marked as Unterweser $\mathrm{km}$. The dark-grey shaded area indicates the location of the turbidity maximum (TM)

and washing were followed by DAPI-staining prior to enumeration by epifluorescence microscopy.

Nucleic acid extraction and PCR amplification of 16S rRNA gene fragments. On board, $50 \mathrm{ml}$ of sample were filtered onto $5 \mu \mathrm{m}$ Nuclepore filters $(47 \mathrm{~mm}$ diameter) to collect particle-associated bacteria. Bacteria passing through the $5 \mu \mathrm{m}$ filter (free-living bacteria) were collected on a $0.2 \mu \mathrm{m}$ Nuclepore filter. DNA was extracted by a slightly modified standard protocol with hot phenol/chloroform, SDS, PVPP (polyvinylpyrrolidonephosphate) and $300 \mathrm{mg}$ per $1.5 \mathrm{ml}$ circonia beads.
The primers GM5F (341F) and 907RM (Muyzer et al. 1998) were used to amplify $550 \mathrm{bp}$ rDNA fragments separated by DGGE (see below). At the $5^{\prime}$-end of the GM5F primer, an additional 40 bp GC-rich nucleotide sequence (GC-clamp) was added to stabilize migration of the DNA fragments in DGGE (Muyzer et al. 1993). PCR amplifications were performed with an Eppendorf Mastercycler (Eppendorf) as follows: $1 \mu$ of extracted DNA (1 to $10 \mathrm{ng}$ ), $10 \mathrm{pmol}$ of each of the appropriate primers, $12.5 \mathrm{nmol}$ of each deoxyribonucleoside triphosphate, $5 \mu$ of $10 \times$ RedTaq $^{\mathrm{TM}}$ PCR buffer (Sigma), $5 \mu$ l of bovine serum albumin (Sigma; final concentration $3 \mathrm{mg} \mathrm{ml}^{-1}$ ) and 0.5 unit of $\operatorname{RedTaq}^{\mathrm{TM}}$ DNA polymerase (Sigma) were adjusted to a final volume of $50 \mu \mathrm{l}$ with PCR-grade water (Sigma). For the primer combination GM5F/907RM, we used a touch down PCR program with a decreasing annealing temperature from 65 to $56^{\circ} \mathrm{C}$ ( 2 cycles at each temperature step) and additional 18 cycles at $55^{\circ} \mathrm{C}$ for a total of 38 cycles. The amplicons were examined on $2 \%$ agarose gels stained with ethidium bromide $\left(1 \mu \mathrm{g} \mathrm{ml}^{-1}\right)$ (Sambrook et al. 1989).

DGGE analysis of PCR products. DGGE was performed with the D-Code system (Bio-Rad Laboratories) according to the protocol of Brinkhoff \& Muyzer (1997): $1 \mathrm{~mm}$ thick $6 \%$ (wt/vol) polyacrylamide gels, $1 \times \mathrm{TAE}$ electrophoresis buffer (40 mM Tris-HCl [pH 8.3], $20 \mathrm{mM}$ acetic acid, $1 \mathrm{mM}$ EDTA), 20 to $70 \%$ denaturant and an electrophoresis time of $20 \mathrm{~h}$ at a constant voltage of $100 \mathrm{~V}$. After electrophoresis, the gels were stained with SYBR Gold (Molecular Probes ${ }^{\circledR}$ ) and visualized by a BioDoc Analyze Transilluminator (Biometra).

A cluster analysis of the DGGE banding patterns was performed using the software GelCompare II, Version 2.5 (Applied Maths). Every gel contained at least 2 lanes with a standard of 3 bands for internal and external normalization and as an indication of the quality of the analysis. Here, we only present data from single gel analyses. We applied 5 to $20 \%$ background subtraction depending on the signal-to-noise ratio of the corresponding gel. Patterns were compared curvebased using Pearson correlation as similarity coefficient and UPGMA (unpaired group method of analysis) to generate the dendrogram. We used the position tolerance optimization option of the software to fit the curves to the best possible match. From the given cophenetic correlation values and the similarity values for the internal standards, the most likely result was chosen. The similarity values for the standards were between 94 and $98 \%$ except in 2 cases (cluster analysis of June 1999 with $92 \%$ and seasonal comparison of TM samples with $84 \%$ ). The analysis of parallel samples from different PCR assays also yielded similarity values between 94 and $98 \%$. We assume that the remaining gap to $100 \%$ is due to errors caused by the 
PCR, slightly different loading amounts, differences in gel staining/destaining and the remaining weak 'smiling' effect, which could not be removed by normalization with the standards. We used the curve-based approach instead of comparing single bands because our own data and Ferrari \& Hollibaugh (1999) showed this analysis to be more robust.

Cloning, sequencing and phylogenetic analysis. DGGE bands were excised by a sterile scalpel and suspended in $100 \mu$ l of water of PCR quality (Sigma). Cloning was done with the Promega pGEM ${ }^{\circledR}-$ T-Easy Vector System II according to the manufacturer's advice. The accuracy of the bands and the position in the gel were double-checked on DGGE gels. Further, we checked the sequences of bands at similar positions by randomly probing several clones of the same ligation reaction. Except in 1 case, sequences from the same reaction were identical (see 'Sequence analysis of DGGE' and 'Results'). Inserts were reamplified with primers M13F and M13R in two $100 \mu \mathrm{l}$ batches using a standard PCR protocol with 30 cycles at an annealing temperature of $50^{\circ} \mathrm{C}$. PCR products were purified with the Qiaquick PCR purification kit (Qiagen) and sequenced using the DYEnamic Direct Cycle sequencing kit (Amersham Life Science) and a DNA Sequencer (Model 4200, LI-COR). Sequencing primers were M13F, M13R, GM5F and 907RM labeled with IRDye $\mathrm{T}^{\mathrm{TM}} 800$. Sequences were compared to those in GenBank using the BLAST function of the NCBI server (available at www.ncbi.nlm.nih.gov). To increase the reliability of the results, the sequences of the primers were not included in the sequence analysis.

Phylogenetic analysis was performed with the ARB software package (available at www.arb-home.de; Strunk et al. 1998). Phylogenetic trees were constructed using parsimony, neighbor-joining and maximumlikelihood analysis. Presented trees were constructed as follows: backbone trees were calculated using maximum-likelihood analysis and almost full length 16S rRNA gene sequences (>1300 bp). About 100 to 150 sequences from different families as suggested in the prokaryotic representative listing in the Ribosomal Database Project II (RDP 2000; rdp.cme.msu.edu/html) and sequences of closest relatives as found by BLAST search were used for the backbone tree. A filter was constructed for every phylogenetic group in focus of the analysis. Hence, alignment positions at which less than $50 \%$ of sequences of the corresponding data set had the same base pairs were excluded from the calculations to prevent uncertain alignments within highly variable positions. Shorter sequences and sequences of the DGGE bands were added afterwards by maximum parsimony using the same filter.

Nucleotide sequence accession numbers. The sequences obtained in this study are available from GenBank under accession nos. AF497859 to AF497903.

\section{RESULTS}

As is typical of estuarine systems, conductivity exhibited strong gradients between Bremen ( $\mathrm{km} \mathrm{0)}$ and the outer reach of the estuary ( $\mathrm{km} 80)$. The values remained below $2 \mathrm{mS} \mathrm{cm}^{-1}$ in the freshwater section between $\mathrm{km} 0$ and 40, except in December 1999 when $4.4 \mathrm{mS} \mathrm{cm}^{-1}$ were recorded, and increased farther downstream to 25 to $40 \mathrm{mS} \mathrm{cm}^{-1}$ in the polyhaline section at $\mathrm{km}$ 80. In June and December 1999, sampling and monitoring could only be done downstream to $\mathrm{km}$ 70 and 65 , respectively, due to strong wind and intense wave action. The temperature ranged between $7^{\circ} \mathrm{C}$ in March 1999 and $23^{\circ} \mathrm{C}$ in August 1999 with a decrease of up to $3^{\circ} \mathrm{C}$ in summer from $\mathrm{km} 0$ to $\mathrm{km} 80$. In May 2000, water temperature was 18.5 to $21^{\circ} \mathrm{C}$ as compared to 13 to $16^{\circ} \mathrm{C}$ in May 1999. Oxygen concentrations ranged between 4.8 and $13.3 \mathrm{mg} \mathrm{O}_{2} \mathrm{l}^{-1}$, corresponding to 80 to $210 \%$ saturation (ARGE Weser 2000). Oxygen minimum corresponded to turbidity maximum.

The phytoplankton of the Weser estuary is largely dominated by the diatom Actinocyclus normanii (Schuchardt \& Schirmer 1991b). Chl a concentrations ranged from $<3$ to $44.6 \mu \mathrm{g} \mathrm{chl} \mathrm{a} \mathrm{l}^{-1}$, with highest concentrations in the freshwater section between May and July, and lowest values in the TM zone during the same period. During summer, chl a concentrations increased again farther downstream of the TM towards the polyhaline section. In November and December, highest

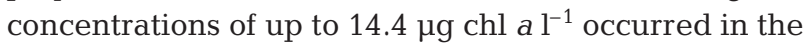
TM zone. Turbidity was greatest between $\mathrm{km} 40$ and 60 at conductivity ranges between 2 and $<18 \mathrm{mS} \mathrm{cm}^{-1}$ except in December 1999 (Fig. 2). SPM ranged between 20 and $400 \mathrm{mg} \mathrm{l}^{-1}$ (Schuchardt 1995) and concentrations of particulate organic carbon (POC) were between 1.6 and $9.8 \mathrm{mg} \mathrm{C}^{-1}$ (ARGE Weser 2000). POC accounts for about 10 to $20 \%$ of SPM (Schuchardt \& Busch 1991). From August to December, the turbidity recordings reached the upper limit of detection of 200 formazine turbidity units (TU/F).

\section{Bacterial numbers}

Total bacterial numbers ranged between $5.2 \times 10^{5}$ $\mathrm{ml}^{-1}$ and $2.0 \times 10^{7} \mathrm{ml}^{-1}$, with highest values between June and August (Fig. 2). From May to August in the freshwater section, numbers were systematically higher than in the marine section, whereas from September until December, numbers in these 2 sections were not significantly different (Student's t-test, $\mathrm{p}<0.01$ ). There was usually a distinct peak of particleassociated bacteria in the TM which some times was also reflected by a peak in total bacterial numbers (Fig. 2). The proportion of particle-associated bacteria 


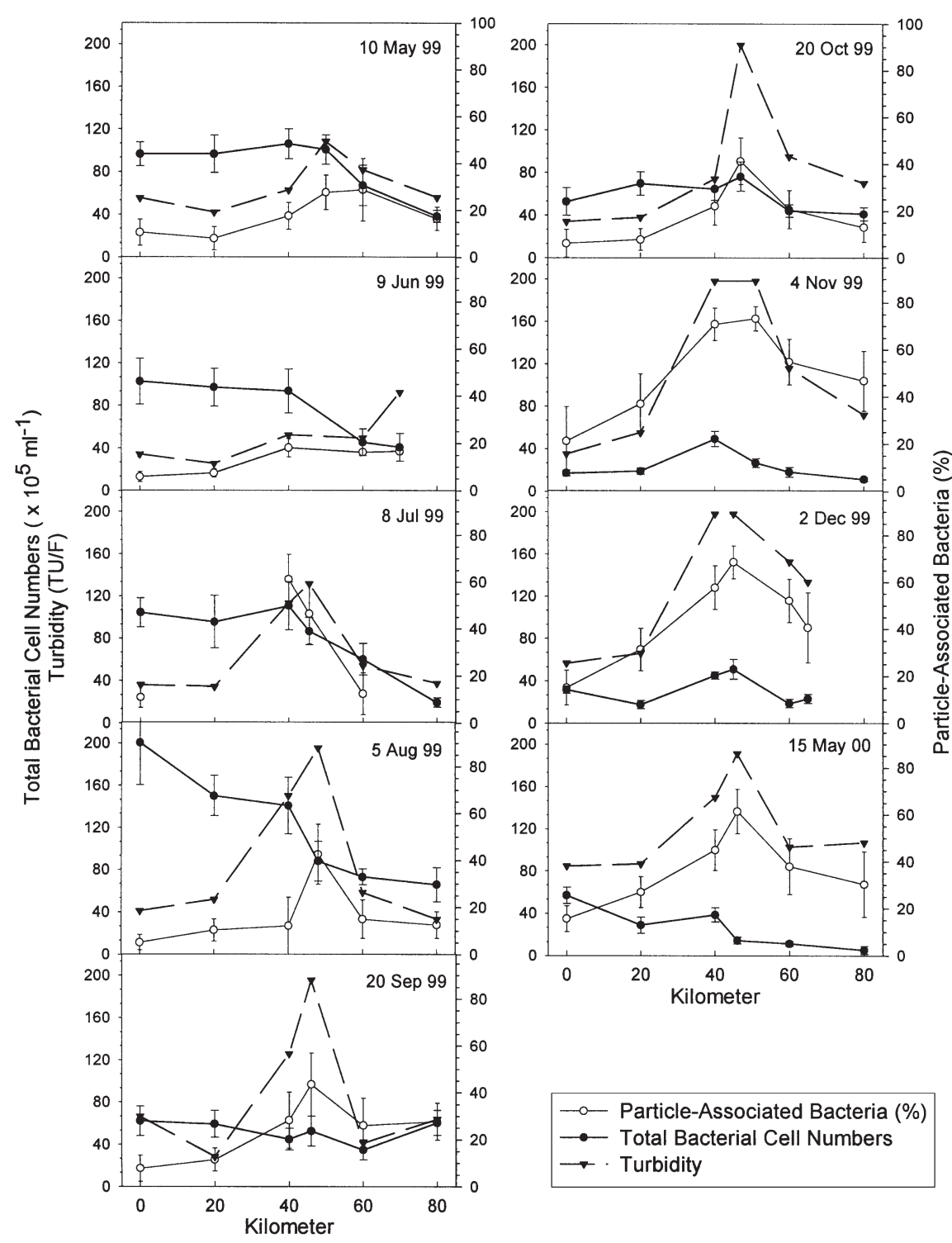

Fig. 2. Turbidity, total bacterial cell numbers and percent of particle-associated bacteria along the Weser estuary from May 1999 to December 1999 and in May 2000 perature, chl a and turbidity as a proxy of the SPM load. We performed analyses of the entire data set and of subsets from $\mathrm{km} \mathrm{0,}$ the TM, km 80, and transects of May 1999 to May 2000 with $95 \%$ confidence limit. The analyses revealed that conductivity was the least important variable (data not shown), as only the percent particle-associated bacteria at the TM was significantly correlated to conductivity. Numbers of total bacteria were significantly correlated to temperature at $\mathrm{km} 0$, the TM and $\mathrm{km} 80$, and to numbers of particleassociated bacteria at $\mathrm{km} 0$ and $\mathrm{km} \mathrm{80,}$ if the values from May 2000 were excluded (Table 1). The correlation coefficient was lowest for the data set at the TM and $\mathrm{km}$ 80. Turbidity was the independent variable most commonly correlated with other variables. Numbers of particle-associated bacteria and in particular of the percent particleassociated bacteria were significantly and closely correlated to turbidity in transects of any given month (Table 1). Chl a was negatively correlated with the turbidity (data not shown) and the percent particle-associated bacteria in May, June and September 1999, and in May 2000, and positively correlated in November 1999 ( $p<0.05$; Table 1). In contrast, chl a was always positively correlated to total bacterial numbers, but significantly only in June, July, September and November 1999, and in May 2000.

\section{FISH analysis}

in the TM reached as high as $70 \%$ of total bacterial numbers in November and December but constituted proportions of only 18 to $30 \%$ in May and June 1999 when the TM was least pronounced.

\section{Relationships between bacterial numbers and physico-chemical variables and chl $a$}

To identify environmental variables important in controlling the dynamics of bacterial abundance, we carried out linear regression analyses of total numbers of bacteria, particle-associated bacteria and percent particle-associated bacteria, using conductivity, tem-
Bacteria as detected by the EUB probe constituted 27 to $78 \%$ of the DAPI-stainable cells of the particleassociated bacteria (Fig. 3). Detection of the probestained bacteria was often difficult because of the high background autofluorescence of the particulate matter on the filter. This problem was even greater with the free-living bacteria, which were smaller than the particle-associated bacteria, thus yielding a weaker fluorescent signal. Because of the low fractions of free-living bacteria detected by the EUB probe (15 to $30 \%$ of DAPI cell counts), we only present results of the particle-associated bacteria. In most samples, and in particular in the freshwater section of the estuary, cells of the CF cluster constituted highest 
Table 1. Linear correlation between temperature, turbidity and chlorophyll a (chl a) concentration, and numbers of total bacteria, particle-associated bacteria (PA bacteria) and percent particle-associated bacteria (\%PA bacteria). Regressions were calculated for total data, data at $\mathrm{km} \mathrm{0,} \mathrm{the} \mathrm{turbidity} \mathrm{maximum} \mathrm{(TM)} \mathrm{zone} \mathrm{and} \mathrm{km} \mathrm{80,} \mathrm{and} \mathrm{for} \mathrm{transects} \mathrm{of} \mathrm{May} \mathrm{1999} \mathrm{to} \mathrm{May} \mathrm{2000.} \mathrm{r}^{2}$ : regression coefficient; -: non significant correlation; $\mathrm{n}$ : number of values per analysis

\begin{tabular}{|c|c|c|c|c|c|c|c|c|c|}
\hline & Total bacteria & $\mathrm{r}^{2}$ & $\mathrm{n}$ & PA bacteria & $\mathrm{r}^{2}$ & $\mathrm{n}$ & $\%$ PA bacteria & $r^{2}$ & $\mathrm{n}$ \\
\hline \multirow[t]{4}{*}{ Temperature } & Total & - & 53 & Total & - & 51 & Total & - & 51 \\
\hline & $\mathrm{km} 0$ & $0.47 / 0.59$ & $9 / 8^{a}$ & $\mathrm{~km} 0$ & $-/ 0.49$ & $9 / 8^{\mathrm{a}}$ & $\mathrm{km} 0$ & - & 9 \\
\hline & $\mathrm{TM}$ & $-/ 0.29$ & $9 / 8^{a}$ & $\mathrm{TM}$ & - & 8 & $\mathrm{TM}$ & - & 8 \\
\hline & $\mathrm{km} 80$ & $-/ 0.32$ & $9 / 8^{a}$ & $\mathrm{~km} 80$ & $-/ 0.34$ & $8 / 7^{a}$ & $\mathrm{~km} 80$ & - & 8 \\
\hline \multirow[t]{13}{*}{ Turbidity } & Total & - & 53 & Total & $0.24 / 0.32$ & $51 / 45^{\mathrm{a}}$ & Total & 0.67 & 51 \\
\hline & $\mathrm{km} 0$ & - & 9 & $\mathrm{~km} 0$ & - & 9 & $\mathrm{~km} 0$ & - & 9 \\
\hline & $\mathrm{TM}$ & 0.40 & 9 & $\mathrm{TM}$ & - & 8 & $\mathrm{TM}$ & 0.34 & 8 \\
\hline & $\mathrm{km} 80$ & - & 9 & $\mathrm{~km} 80$ & - & 8 & $\mathrm{~km} 80$ & 0.30 & 8 \\
\hline & May 99 & - & 6 & May 99 & 0.85 & 6 & May 99 & 0.81 & 6 \\
\hline & Jun 99 & 0.59 & 5 & Jun 99 & - & 5 & Jun 99 & 0.49 & 5 \\
\hline & Jul 99 & - & 6 & Jul 99 & 0.72 & 4 & Jul 99 & 0.83 & 4 \\
\hline & Aug 99 & - & 6 & Aug 99 & 0.78 & 6 & Aug 99 & 0.63 & 6 \\
\hline & Sep 99 & - & 6 & Sep 99 & 0.65 & 6 & Sep 99 & 0.61 & 6 \\
\hline & Oct 99 & - & 6 & Oct 99 & 0.90 & 6 & Oct 99 & 0.95 & 6 \\
\hline & Nov 99 & 0.59 & 6 & Nov 99 & 0.82 & 6 & Nov 99 & 0.93 & 6 \\
\hline & Dec 99 & 0.42 & 6 & Dec 99 & 0.73 & 6 & Dec 99 & 0.91 & 6 \\
\hline & May 00 & - & 6 & May 00 & - & 6 & May 00 & 0.89 & 6 \\
\hline \multirow[t]{9}{*}{ Chl a } & May 99 & - & 6 & May 99 & 0.40 & 6 & May 99 & 0.69 & 6 \\
\hline & Jun 99 & 0.65 & 5 & Jun 99 & - & 5 & Jun 99 & 0.38 & 6 \\
\hline & Jul 99 & 0.45 & 6 & Jul 99 & - & 4 & Jul 99 & - & 4 \\
\hline & Aug 99 & - & 6 & Aug 99 & - & 6 & Aug 99 & - & 6 \\
\hline & Sep 99 & 0.66 & 6 & Sep 99 & - & 6 & Sep 99 & 0.37 & 6 \\
\hline & Oct 99 & - & 5 & Oct 99 & 0.38 & 5 & Oct 99 & - & 5 \\
\hline & Nov 99 & 0.40 & 6 & Nov 99 & 0.75 & 5 & Nov 99 & 0.93 & 6 \\
\hline & Dec 99 & - & 6 & Dec 99 & - & 6 & Dec 99 & - & 6 \\
\hline & May 00 & 0.40 & 6 & May 00 & - & 6 & May 00 & 0.75 & 6 \\
\hline
\end{tabular}

proportions of DAPI cell counts (Fig. 3). There was a trend of decreasing proportions of these cells towards the marine section as shown by the mean proportions $\pm \mathrm{SE}$ of this cluster of $28.4 \pm 8.9,15.7 \pm 8.4$ and $14.0 \pm$ $3.7 \%$ of the DAPI cell counts in the freshwater section, the TM and the polyhaline section, respectively. Mean percentages of the CF cluster in the freshwater and marine sections were significantly different (Student's $t$-test, $\mathrm{p}<0.01)$. Proportions of the $\alpha-$, $\beta$ - and $\gamma$ Proteobacteria constituted around $10 \%$ of the DAPI cell counts without systematic patterns, neither seasonally nor downstream. In the freshwater section, the sum of the Proteobacteria and CF detected by the various probes amounted to $107 \%$ of the EUB probe as a mean of the 4 mo. From May to August, the range was 91 to $98 \%$; however, in November, because of a rather low detection efficiency with the EUB probe, the sum of all 4 probes amounted to $146 \%$. At the TM, and in the marine section, the mean percentage accounted for by the 4 probes constituted 71 and $76 \%$ of the EUB probe for the 4 mo.

\section{DGGE analysis}

Typically, banding patterns exhibited pronounced differences between the freshwater and marine section. Between 20 and 30 bands were separated on 1 lane (Fig. 4). Some bands, e.g. band 1 in Fig. 4 (see WL8-1 in Table 2), were most pronounced in the freshwater section ( $\mathrm{km} 0$ and 20) and were also present in the brackish section ( $\mathrm{km} \mathrm{40,TM,} \mathrm{km} \mathrm{60),} \mathrm{but} \mathrm{disap-}$ peared in the marine section ( $\mathrm{km} 80)$. Others occurred mainly in the brackish section (bands 10 and 11 in Fig. 4; see WB8-10 and WB8-11 in Table 2) or in the marine section (bands 14 and 15 in Fig. 4; see WM8-14 and WM8-15 in Table 2). There were also differences between the composition of particle-associated and free-living bacterial communities, with some bands occurring only in one or the other fraction even though some bands occurred in both.

The cluster analysis of DGGE banding patterns from transects in April, May, June, August and November 1999 substantiated the existence of distinct bacterial 


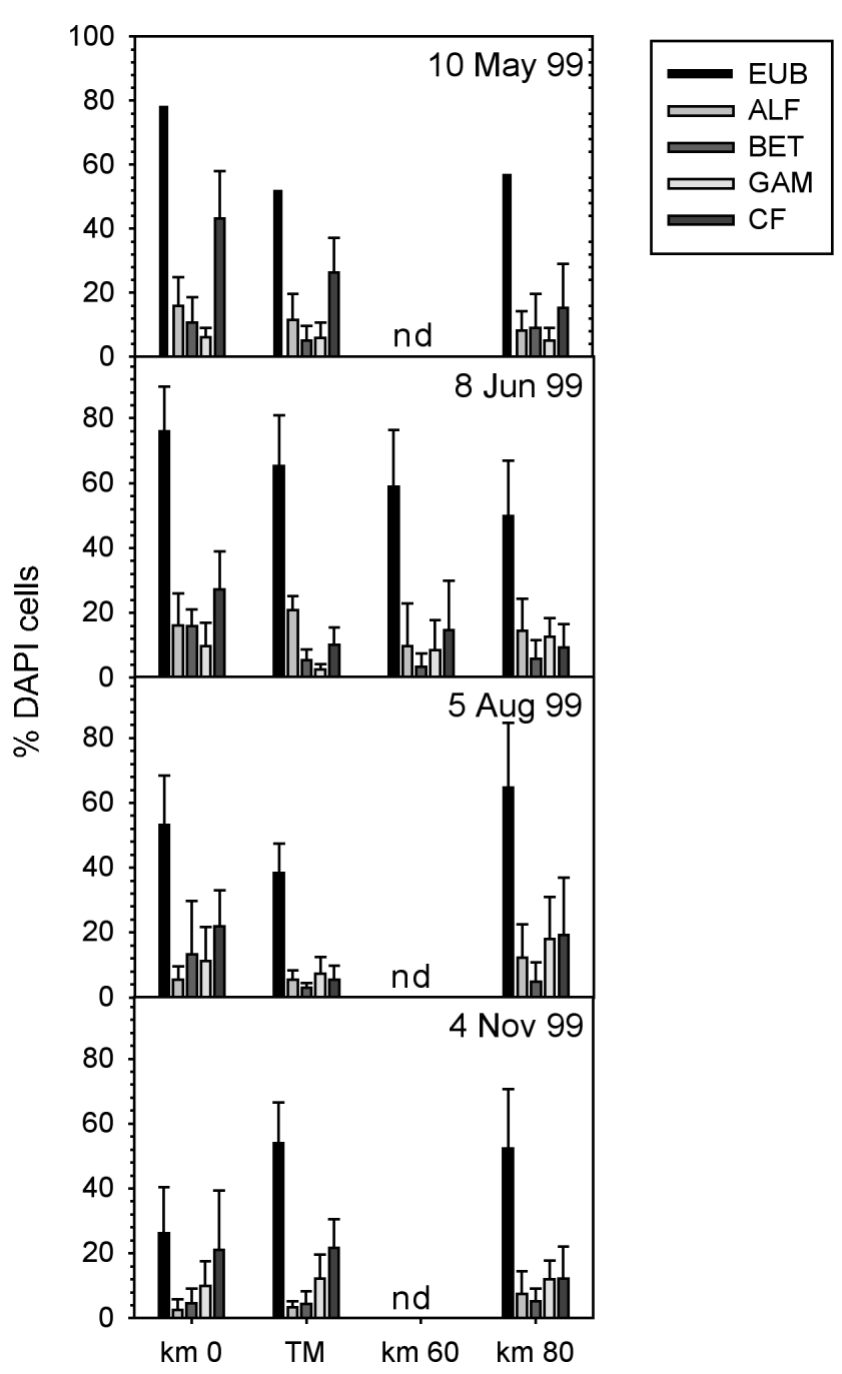

Fig. 3. Proportions of Bacteria (EUB), $\alpha-(\mathrm{ALF}), \beta-(\mathrm{BET})$ and $\gamma$ Proteobacteria (GAM), and Cytophaga/Flavobacteria (CF) in the particle-associated bacterial community as percent of DAPI cell counts along the Weser estuary. Mean values $\pm \mathrm{SE}$ from samples taken in May, June, August and November 1999 are given; nd: not determined

communities in the freshwater, brackish and marine section. Particle-associated and free-living bacterial communities within these sections clustered together (Figs. 4 \& 5). Only in April 1999 was there no distinct marine sub-cluster because we only sampled downstream to $\mathrm{km}$ 70 and the TM was located at km 60. In May, the freshwater sub-clusters included the sample from $\mathrm{km} \mathrm{40,}$ which usually clustered together with the brackish samples, because its conductivity was lower than at all other sampling dates. In June, when no pronounced TM occurred (Fig. 2), banding patterns of the particle-associated bacterial communities in the freshwater and brackish sections formed distinct sub-clusters, whereas banding patterns of the free-living bacterial communities between $\mathrm{km} 0$ and 40 clustered closely together.
Seasonal variations of the bacterial communities at the TM were also examined by cluster analysis. The major difference occurred between spring, i.e. March, April and May 1999, and summer and fall, i.e. July, August and November 1999 (Fig. 6). A transitional phase occurred in June when the particle-associated bacterial community clustered together with the spring communities, whereas the free-living bacterial community clustered within the summer/fall communities. The composition of the bacterial communities from May 2000 was more similar to those of the summer/fall communities than to those of spring 1999.

\section{Sequence analysis of DGGE bands}

The 44 bands excised from May, August and November gels were cloned and sequenced. We focused on the most intense bands occurring repeatedly or on peculiar bands occurring only in 1 of the 2 bacterial sub-communities. In the marine section, usually only 1 very intense band occurred throughout the study period, whereas in the brackish and freshwater section more bands of high and similar intensity occurred. Twenty-six bands were from the freshwater, 11 from the brackish and 7 from the marine section. According to BLAST, 17 clones affiliated with $\alpha$-Proteobacteria, 9 with $\beta$-Proteobacteria, 5 with Cytophaga/Flavobacteria, 7 with Actinobacteria and 6 were identified as chloroplast-like sequences (Table 2). Surprisingly, there was no representative of $\gamma$-Proteobacteria among the clones. All 7 marine clones belonged to $\alpha$-Proteobacteria and represented 3 different phylotypes. The most intense band in marine samples of gels from May, August and November was $\geq 99 \%$ similar to clone NAC11-3 (Table 2; Gonzales et al. 2000) and was detected in all samples from April and November in both bacterial sub-communities. The same band was also detected at the TM in November. The other 2 marine phylotypes were detected in different seasons as well. One of the most intense bands in the freshwater section (WL8-1, band 1 in Fig. 4, Table 2), which occurred repeatedly, was identified as an Actinobacteria clone related closely to clones of uncultured bacteria from various lakes. Two other intense bands of the particle-associated bacterial community in the freshwater section sequenced from the May 1999 gel were $\alpha$-Proteobacteria clones related closely to Rhodobacter capsulatus and Paracoccus kawasakiensis (WL5-5 and WL5-16 in Fig. 7A) and Brevundimonas sp. (WL5-15 in Fig. 7A, Table 2). Two intense bands which occurred in May and November from the freshwater to the oligohaline reach ( $\mathrm{km} \mathrm{60),} \mathrm{were} \mathrm{identified} \mathrm{as} \beta$-Proteobacteria which clustered with sequences of uncultured bacteria from various lakes (WL5-9 and WL11-5 in 


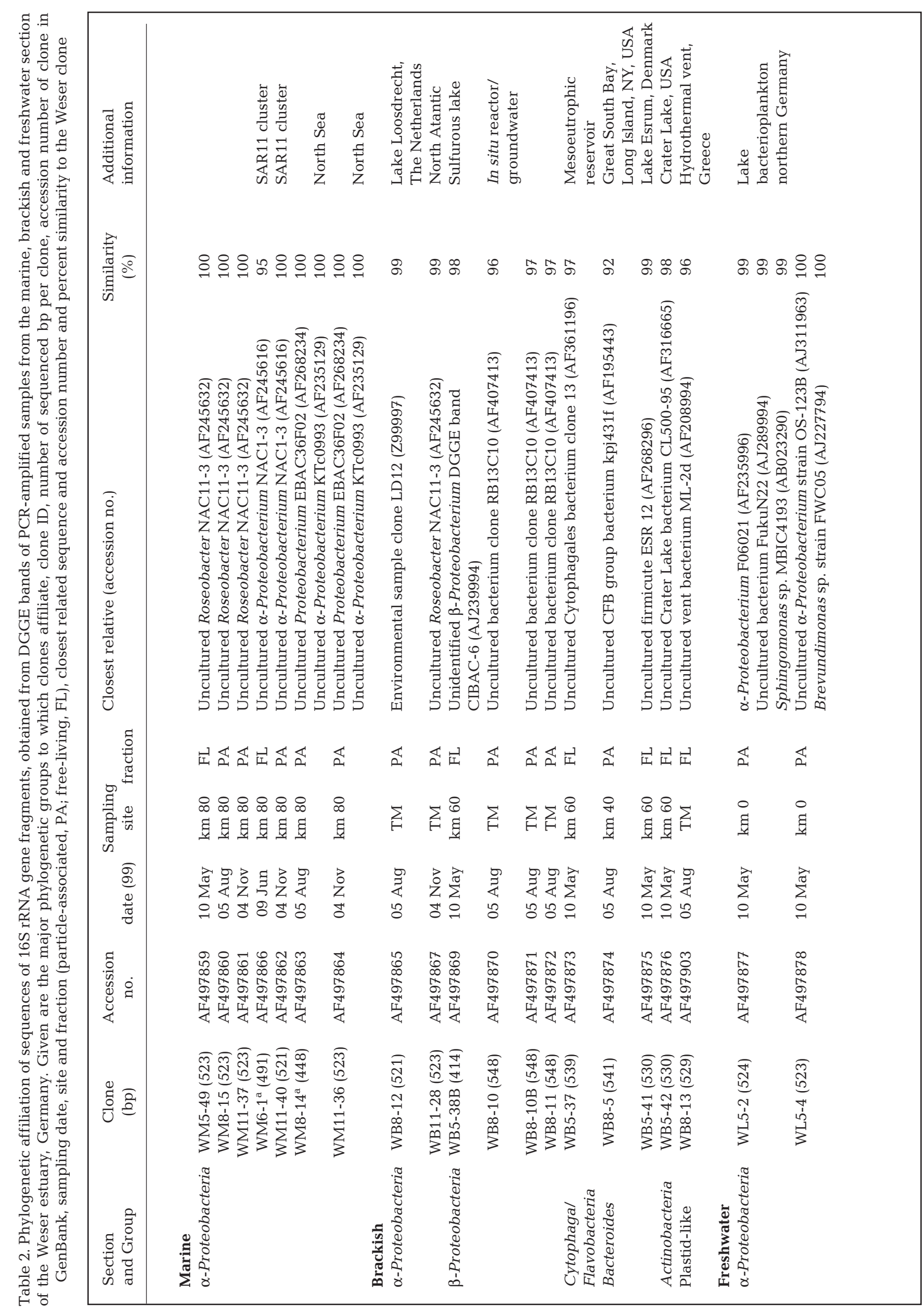




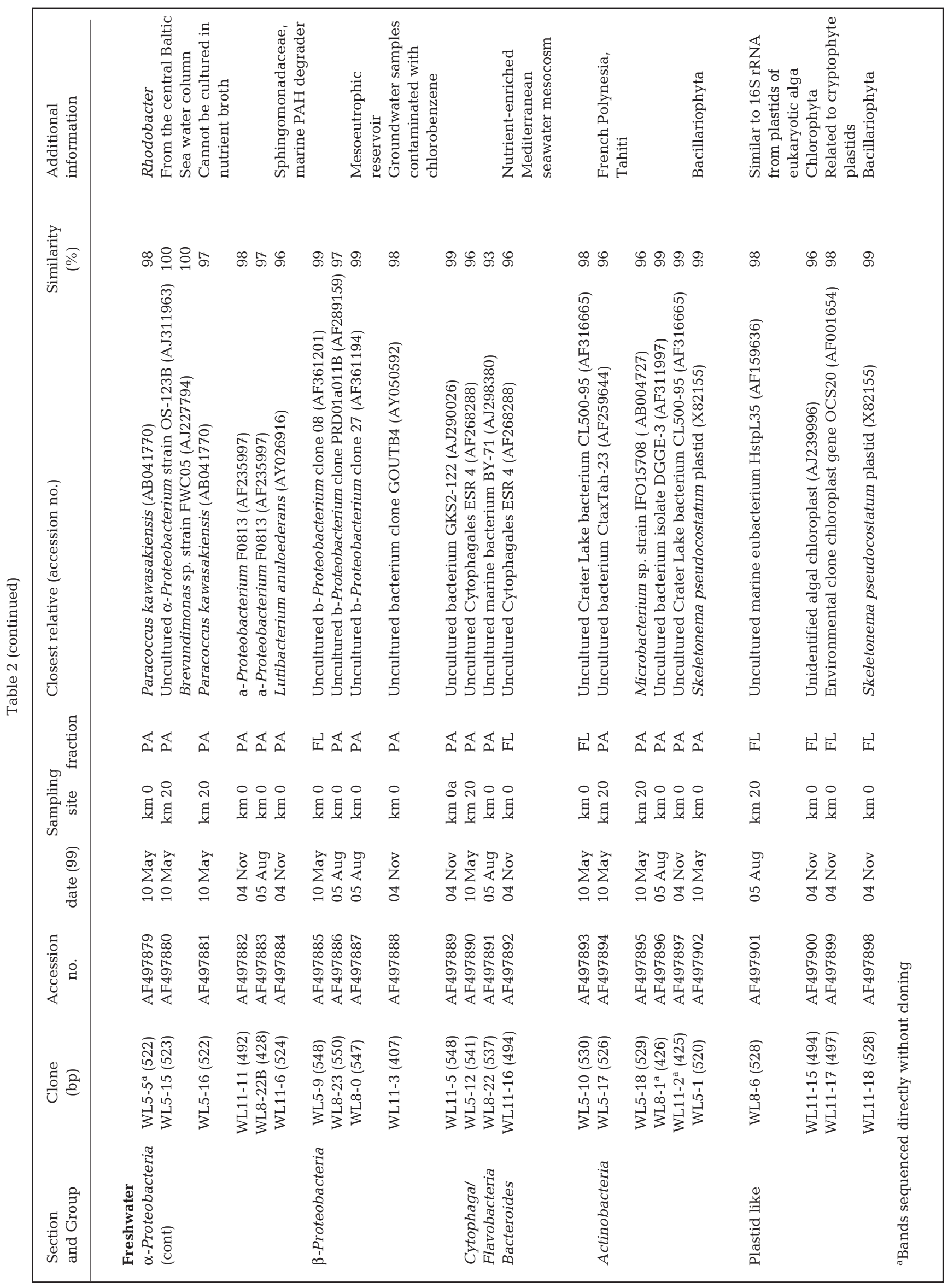




\section{Pearson correlation}
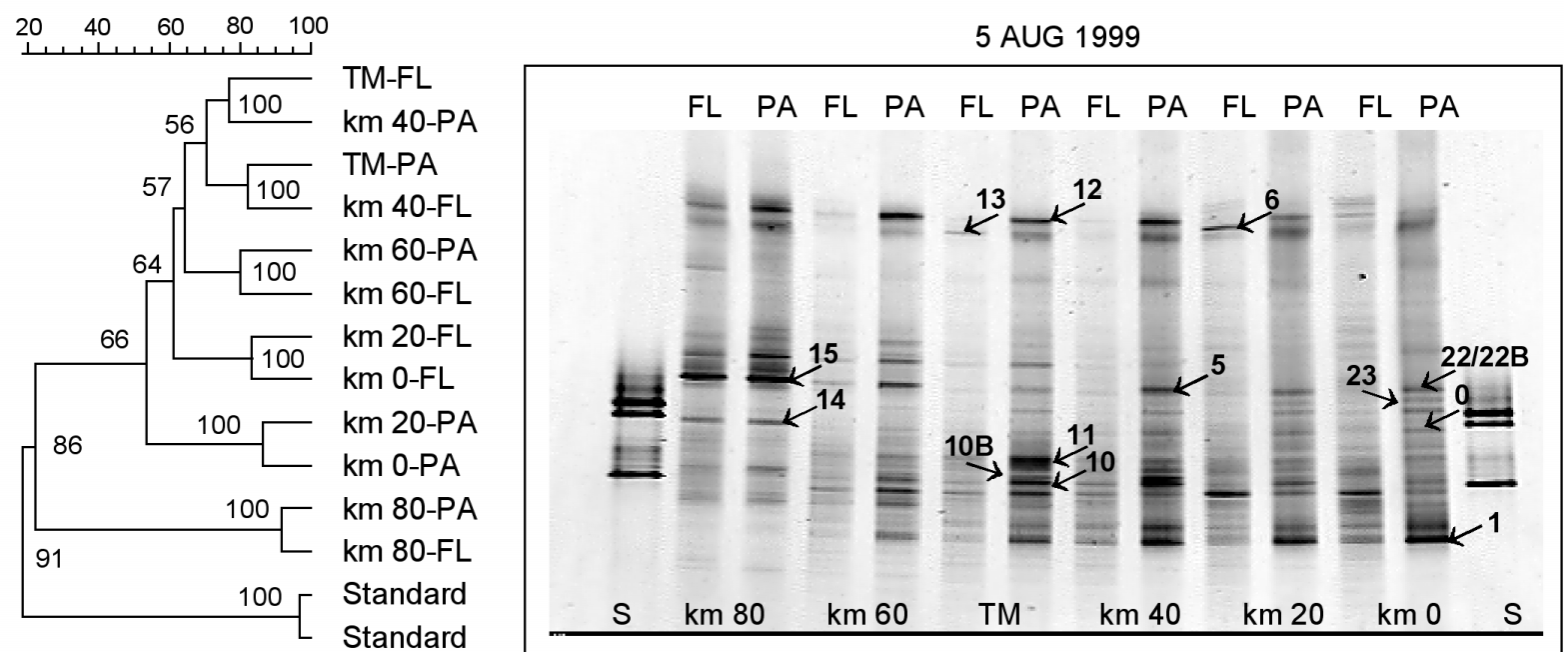

Fig. 4. Inverted DGGE profile of PCR-amplified 16S rRNA gene fragments and corresponding cluster analysis of samples taken along the Weser estuary in August 1999. Numbers in the gel denote bands which were excised and cloned for sequence analysis. The cluster analysis was done curve based using Pearson correlation and UPGMA. Numbers in the dendrogram indicate calculated cophenetic correlations. Sites indicated as Unterweser $\mathrm{km}$. Bacterial fractions: FL = free-living; PA = particle-associated; $\mathrm{S}=$ standard

Fig. 7B). We did not obtain these sequences from the most intense bands in August, but instead from 3 bands that occurred in the TM and affiliated closely to Rhodoferax fermentans as the next described species (WB8-10, WB8-10B and WB8-11 in Figs. 4 \& 7B). The same band was also found in the brackish section in May (WB5-38B).

The prominent bands on the gel in Fig. 4 numbered 15 from km 80 (WM8-15), 5 from km 40 (WB8-5) and 22 from km 0 (WL8-22a), occurring at similar positions, represented completely different clones: uncultured Roseobacter NAC11-3 (AF245632), and clones related to uncultured bacterium kpj431f (AF195443) and uncultured marine bacterium BY-71 (AJ298380) of the CF cluster (Fig. 7C, Table 2). In fact, band 22 at $\mathrm{km} 0$ of this gel contained not only the clone of this uncultured bacterium of the CF cluster, but another clone affiliating to $\alpha$-Proteobacteria (WL8-22b). The similar banding position of these 2 clones was verified by a separate DGGE analysis.

\section{DISCUSSION}

The Weser estuary, like many other estuarine ecosystems, exhibited a turbidity maximum which was well pronounced from July 1999 until May 2000. The significance of this reach of the highest SPM load for bacterial decomposition processes is documented by the fact that the oxygen minimum zone existed in this region, that (during the period mentioned) particle- associated bacteria constituted 40 to $70 \%$ of total bacterial numbers, and also that a close correlation existed between numbers and percentages of particle-associated bacteria and turbidity. These results corroborate previous findings on particle-associated bacteria in the Weser estuary (Schuchardt \& Busch 1991, Schuchardt \& Schirmer 1991a). Taking into account that activities of ectoenzymatic hydrolysis and substrate uptake per cell are much higher for particle-associated bacteria than for free-living bacteria (Simon 1985, Iriberri et al. 1987, Smith et al. 1992, Hoppe et al. 1993), these results emphasize, in line with previous reports (Bell \& Albright 1981, Bent \& Goulder 1981, Crump et al. 1998), the significance of particle-associated bacteria for decomposition processes in estuarine TM and in general in estuaries with a high SPM load.

The major aim of our study was to examine whether different bacterial communities are established in the various sections of the Weser estuary as a result of the salinity gradient, the SPM load and the seasonality. The shift from a community dominated by free-living bacteria in the freshwater section to one with a much higher fraction of particle-associated bacteria in the TM, in fact suggests that the community composition undergoes changes. Differences in the community structure between free-living and particle-associated bacteria have been demonstrated in freshwater, estuarine and in marine systems (DeLong et al. 1993, Acinas et al. 1999, Crump et al. 1999, Phillips et al. 1999, Knoll et al. 2001, Schweitzer et al. 2001). The FISH data provide evidence for a generally important role of bacteria of the $\mathrm{CF}$ 


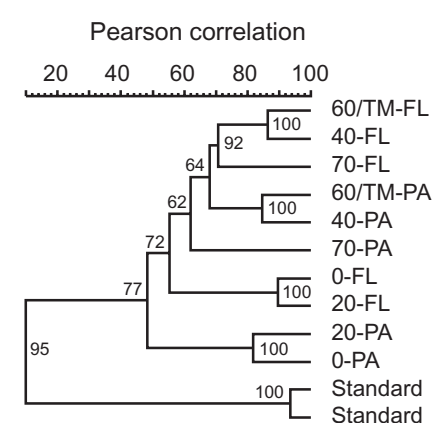

Apr 99

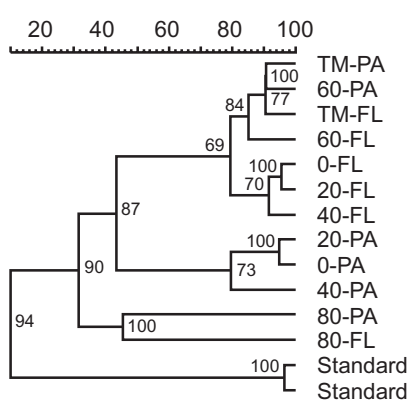

May 99

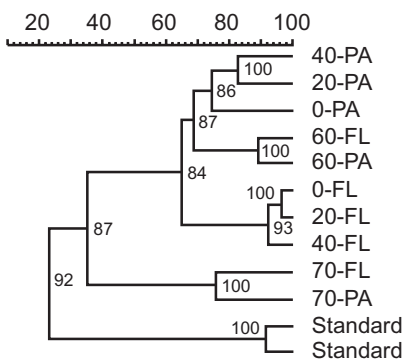

Jun 99

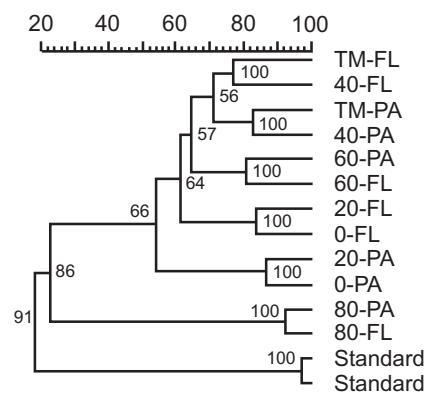

Aug 99

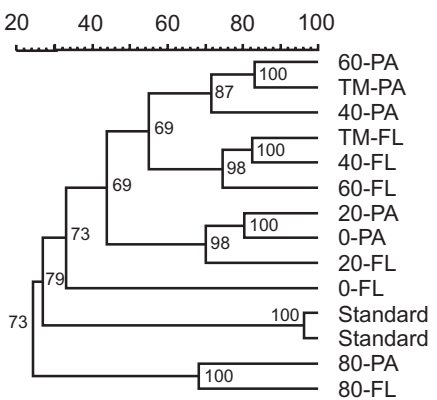

Fig. 5. Cluster analysis of the similarity of DGGE profiles of downstream transects of April, May, June, August and November 1999. For details of cluster analysis and abbreviations, see legend of Fig. 4. Note that in April the turbidity maximum (TM) was at $\mathrm{km} 60$

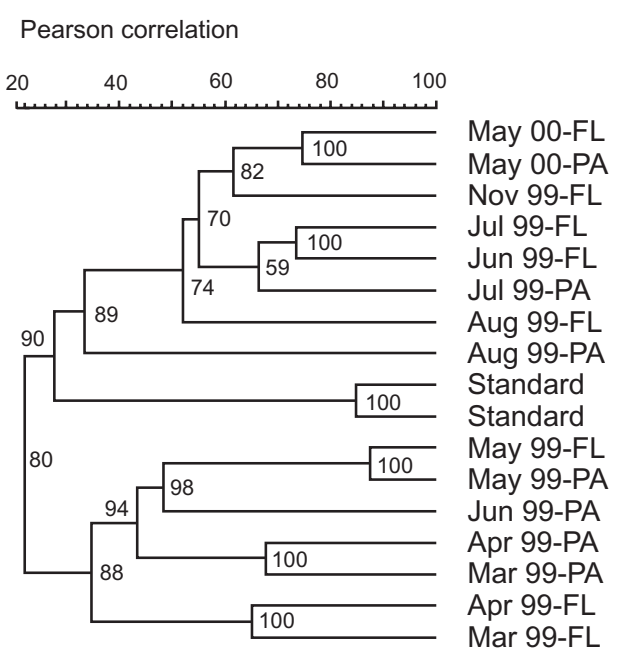

Fig. 6. Cluster analysis of the similarity of DGGE patterns from the turbidity maximum (TM) at different sampling dates. For abbreviations, see legend of Fig. 4

cluster in the particle-associated bacterial community in the Weser estuary because this cluster often constituted the highest proportions of DAPI-stainable cells. Also, other studies examining the composition of particle- and biofilm-associated bacterial communities in the river Elbe, Germany and its estuary, found high proportions of cells of the CF cluster (Böckelmann et al. 2000, Brümmer et al. 2000, Simon et al. 2002). $\alpha$-, $\beta$ - and $\gamma$-Proteobacteria, in our study, in most cases were of lower significance than $\mathrm{CF}$, irrespective of the salinity. Often, no significant difference existed among the 3 subclasses of Proteobacteria. These findings are in contrast to other reports on the composition of bacterial communities, which showed a pronounced dominance of $\beta$-Proteobacteria in freshwater environments and of $\alpha$ - or $\gamma$-Proteobacteria in oligohaline and marine environments (Glöckner et al. 1999, Böckelmann et al. 2000, Brümmer et al. 2000, Bouvier \& del Giorgio 2002, Simon et al. 2002). At present, we are unable to decide whether this is a result of the often rather low detection efficiency of the group-specific probes or a specific feature of the Weser estuary. Further, we do not know whether this finding is only restricted to the particle-associated bacteria or also applies to the free-living bacteria, which due to the rather small size and the high autofluorescing background, could not be analyzed satisfactorily by FISH.

As compared to other estuaries, the Weser estuary contains a rather high particle load. Therefore, we separated the particle-associated and free-living bacterial communities by filtration through $5 \mu \mathrm{m}$ pore size Nuclepore filters and not by 1 or $3 \mu \mathrm{m}$, as has often been done in similar studies (Kirchman \& Mitchell 1982, Wright \& Coffin 1983, Palumbo et al. 1984, Simon 1985, Crump et al. 1998, Hollibaugh et al. 2000). At a low particle load, $>90 \%$ of the free-living bacteria pass 
through 1 or $3 \mu \mathrm{m}$ filters (Wright \& Coffin 1983, Palumbo et al. 1984), which predominantly retain particle-associated bacteria under these conditions. However, with increasing particle load, clogging of these filters increases and thus, the filters retain a greater fraction of the free-living bacteria and a clear-cut separation of these 2 bacterial sub-communities can be rather problematic.

The cluster analysis of our DGGE banding patterns provided strong evidence that bacterial communities of distinctly different composition existed in the freshwater, brackish and marine section of the Weser estuary and that temporal variations occurred as well. Further, differences were also present between the composition of the free-living and particle-associated bacterial communities, and usually more pronounced in the freshwater than in the brackish and marine section. Interestingly, Crump et al. (1998) reported that the residence time of particles in the Columbia River estuary was much longer than it was in bulk water. If this also applies to the TM of the Weser estuary, the more stable composition of the particle-associated bacterial community at the TM may be due to the longer particle retention time as compared to that of the bulk water. An indication of an extended residence time of the particles and their associated bacterial community in the TM of the Weser estuary may be that, on the basis of the cluster analysis, the composition of the particle-associated bacterial community at the TM in June 1999 remained like in May 1999, whereas that of the free-living bacterial community in June 1999 diverged from that in May and was more similar to that in July 1999.

The DGGE pattern at the TM of May 2000 clustered together with those of June to November 1999 and not with those of March to May/June 1999. We assume that this was a result of the enhanced temperature in May 2000 which was similar to that in summer 1999 (June to August). Because of the earlier warming of the estuary, the bacterial community presumably had shifted to the summer community already in May 2000 as compared to June and July in the previous year. For unknown reasons, the number of total bacteria in this month was substantially lower than in the previous year in August but also in May. Obviously, another effect other than tempera- ture, e.g. grazing or viral lysis, controlled bacterial cell numbers at this sampling date.

Our results on the diversity of estuarine bacterial communities substantiate and specify previous findings on the diversity of bacterial communities from a few other estuaries. In San Francisco Bay, characterized by lower chl a concentrations than the Weser Estuary and a high percentage of inorganic SPM,

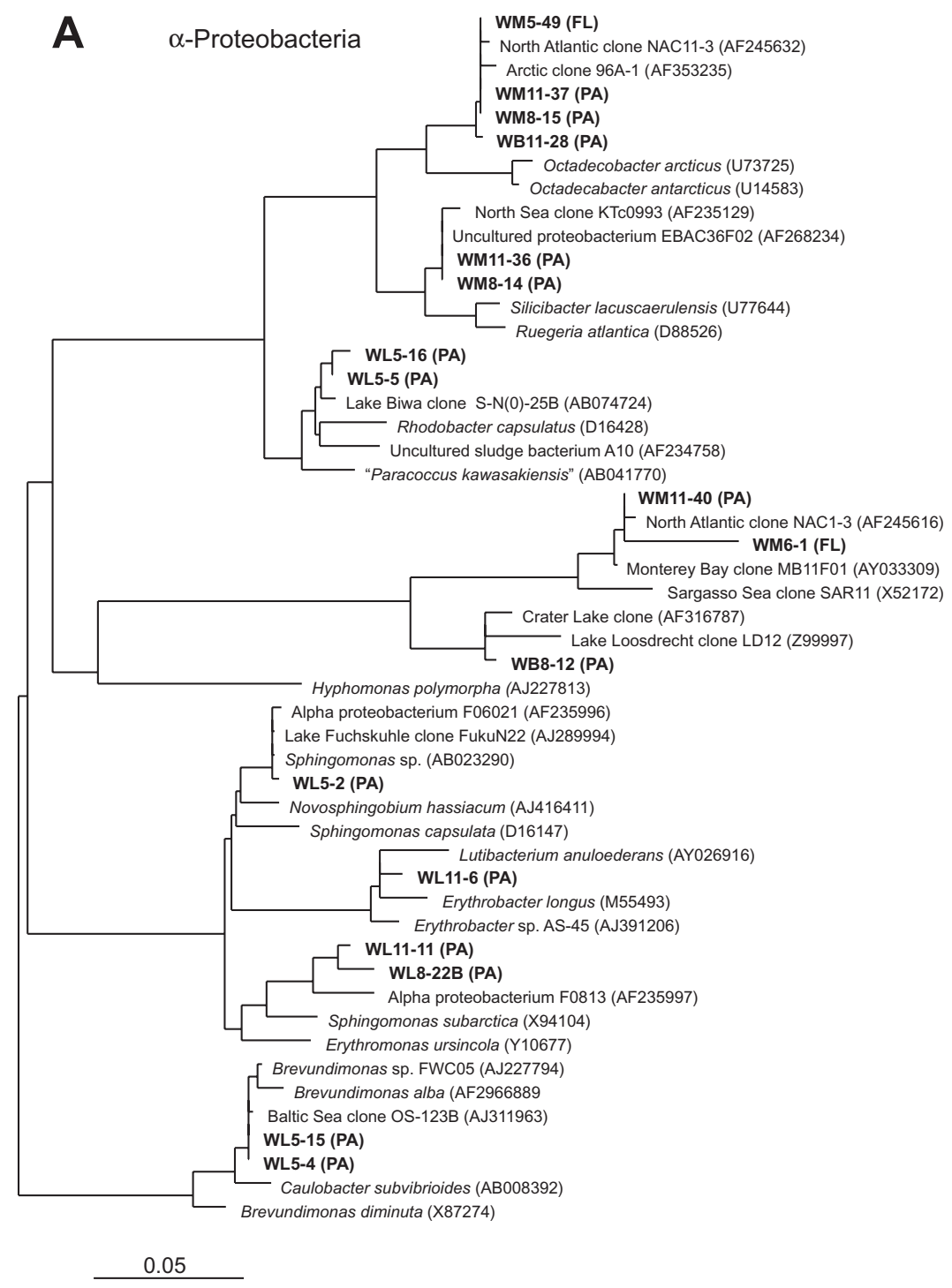

Fig. 7. Phylogenetic trees of the phylogenetic relationships of sequenced clones of DGGE bands from samples taken in May, August and November 1999. (A) $\alpha$-Proteobacteria, (B) $\beta$-Proteobacteria, (C) Actinobacteria (HGC) and Cytophaga-Flavobacteria bacteroides (CFB) phylum. A backbone tree based on maximum likelihood analysis was constructed with almost complete (>1300 nucleotides) sequences. Alignment positions at which less than $50 \%$ of the corresponding sequences had the same base pairs were excluded. Sequences shorter than 1300 nucleotides were added with maximum parsimony using the same filter. The scale bar indicates $5 \%$ estimated sequence divergence, subclusters beta I, II and IV were adopted from Glöckner et al. (2000) 

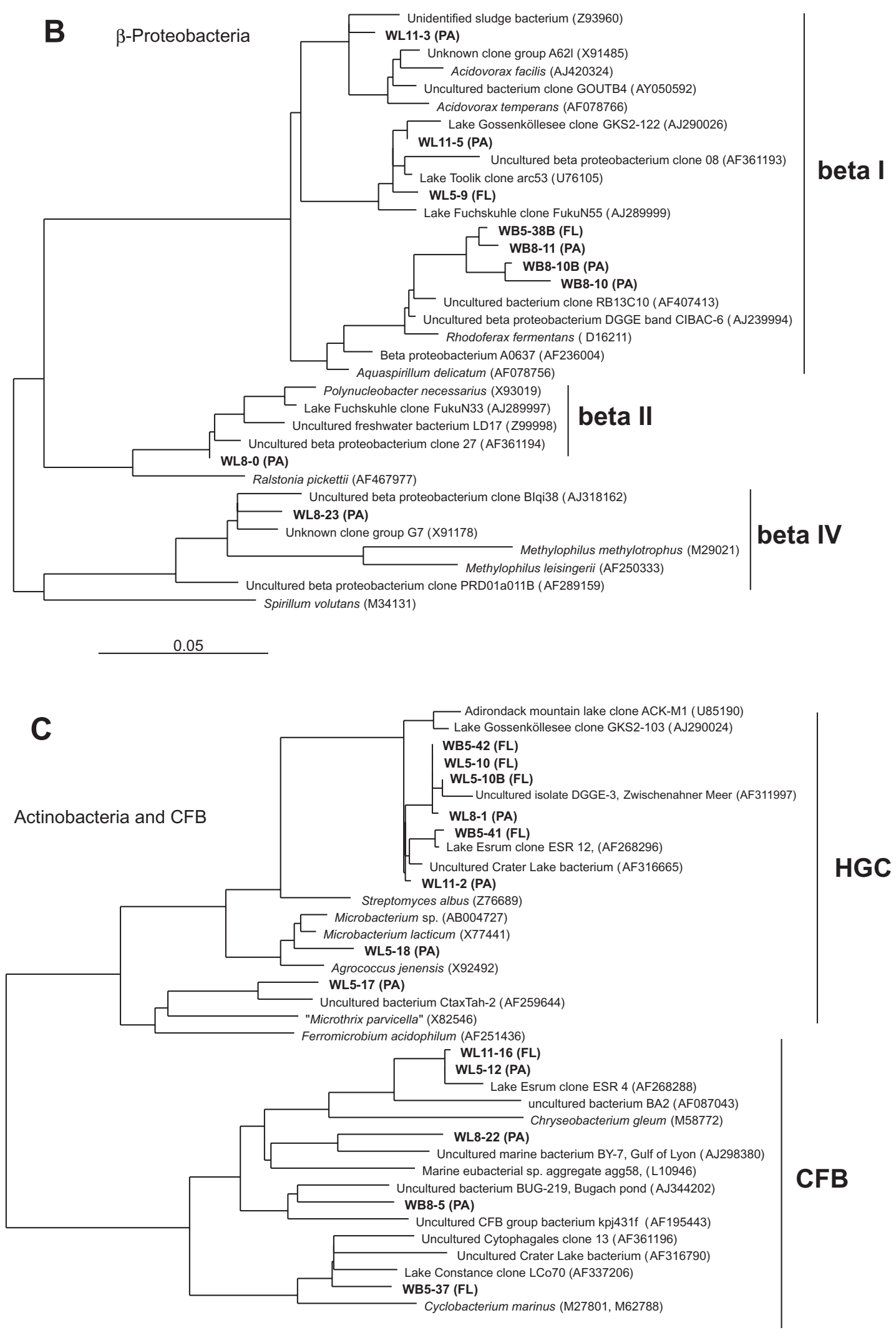

Fig. 7 (continued) 
Hollibaugh et al. (2000) examined banding patterns of PCR-amplified 16S rRNA gene fragments by DGGE and found that the bacterial communities in various salinity regions exhibited differences, whereas the sub-communities on particles and in the surrounding water were basically similar. Bidle \& Fletcher (1995), comparing banding patterns of the 5S rRNA, however, found differences between particle-associated and free-living bacterial communities in Chesapeake Bay. This may indicate that the composition of the particulate material, and possibly also the ratio of organic and inorganic material, is important in determining the relative composition of particle-associated and freeliving bacterial communities. Bouvier \& del Giorgio (2002) studied the composition of the free-living bacterial community in 2 estuarine tributaries of Chesapeake Bay using FISH and found a pronounced dominance of $\beta$-Proteobacteria in the freshwater section and of $\alpha$-Proteobacteria in the oligohaline section. $\mathrm{CF}$ and $\gamma$-Proteobacteria were of low significance throughout the estuarine salinity gradient. Crump et al. (1999) studied the composition of particle-associated and free-living bacteria in the Columbia River estuary on the basis of clone libraries of 16S rRNA gene fragments and found differences between the freshwater, estuarine and marine sections, as well as between the particle-associated and free-living bacterial communities. Crump et al. (1999) postulated that a specific bacterial community in the TM existed of which a substantial fraction occurred neither in the freshwater nor in the marine section. Our data support this idea and show that this community consists of bacteria also occurring in the freshwater as well as in the polyhaline section; however the community also comprises bacteria which predominantly or exclusively occur in the brackish section, as indicated by prominent and intense DGGE bands. Phylotypes of most of these bacteria have been found in other freshwater systems (Table 2; e.g. Zwart et al. 1998, Casamayor et al. 2000, Riemann \& Winding 2001, Šimek et al. 2001, Urbach et al. 2001). Hence, they presumably have a wider salt tolerance than other freshwater and/or marine bacteria, allowing them to prosper in an environment in which the growth of other bacteria is more limited. If this assumption holds true, estuaries do not only provide a niche for typical eukaryotic communities (Nybakken 2001) but also for prokaryotic ones.

An important question for the interpretation of our DGGE results are possible biases of this method. The detection limit of PCR-amplified 16S rRNA gene fragments in DGGE analyses has been estimated to be $1 \%$ of the total amplified 16S rDNA (Muyzer et al. 1993). On the other hand, there is evidence of biased PCR reactions due to selective amplification (Cottrell \& Kirchman 2000). This may be a reason why we did not detect any $\gamma$-Proteobacteria in our sequence analysis and no clone of the CF cluster in the marine section, despite the detection of cells of these subclasses by FISH. We can not rule out, however, that we did amplify 16S rRNA gene fragments of these subclasses but just did not pick any of these bands for the sequence analysis. We do assume that, despite these shortcomings, the clones we detected on our gels, and in particular the most intense ones, represented the great majority of the bacteria present in the Weser estuary. These findings may appear to contradict the FISH results. However, it has to be kept in mind that the applied group-specific oligonucleotide probes target the majority, if not all, cells of the respective group, whereas the picked DGGE bands target single dominant phylotypes. Hence, the DGGE analysis complements the FISH analysis, shedding light on the diversity within the CF cluster and the $\alpha$ - and $\beta$ Proteobacteria.

Our sequencing analysis of the DGGE bands indicated the existence of Actinobacteria in particleassociated and free-living bacterial communities in the freshwater and brackish sections. High abundances of Actinobacteria have been detected by FISH in a mountain lake, constituting as an annual mean $28 \%$ of the DAPI-stainable bacteria; however, these were not detected by the general probe for Bacteria (EUB338; Glöckner et al. 2000). We did not apply a probe to detect Actinobacteria by FISH but assume, on the basis of the DGGE and sequencing analysis, that also in the Weser estuary Actinobacteria constitute a significant fraction of the particle-associated and free-living bacterial community. This assumption may also explain our rather low detection efficiencies with the EUB probe.

Our results of the cluster analysis and any other comparable results need a cautious remark on their interpretation. As indicated by the sequence analysis of cloned bands occurring at similar positions in lanes with samples from $\mathrm{km} 0, \mathrm{~km} 40$ and $\mathrm{km} \mathrm{80,} \mathrm{these}$ sequences affiliated to different phylogenetic clusters, $\mathrm{CF}$ and $\alpha$-Proteobacteria. Hence, the cluster analysis may yield the same similarity index for banding patterns of samples of different origin even though bands of similar position may represent completely different clones. The occurrence of bands representing chloroplast-like sequences such as in our DGGE profile of the free-living bacterial community at km 0 from November 1999 further bias the banding patterns of the bacterial communities. These biases are of general significance and suggest that a cluster analysis should never be performed without any sequence analysis of representative bands.

The sequence analysis of the DGGE bands revealed that the great majority of the phylotypes affiliated with 
sequences of uncultured bacteria found in other aquatic environments. Interestingly, the sequences within the CF cluster in general were only distantly related to other phylotypes and even more distantly to described species (Fig. 7C, Table 2). Two of these sequences were most prominent in the particle-associated fraction and not detectable in the free-living bacterial fraction. Most of the sequences affiliating to Actinobacteria fell into 1 narrow cluster which also contained other phylotypes from Crater Lake (Urbach et al. 2001), mesotrophic and eutrophic lakes in Germany (Jaspers et al. 2001, Zwisler et al. 2003), The Netherlands (Zwart et al. 1998) and Denmark (Riemann \& Winding 2001). These phylotypes represented prominent bands in our DGGE patterns and occurred repeatedly throughout the study period in the freshwater and brackish section. In line with the other studies and the study by Glöckner et al. (1999), these results indicate that Actinobacteria of this cluster are important players in the turnover of organic matter in freshwater ecosystems even though information on their specific role is still lacking. There is only 1 report that Actinobacteria of this cluster accumulated when a mixotrophic Ochromonas sp. grazed on mixed bacterial communities (Pernthaler et al. 2001). Hence, Actinobacteria obviously have a selective advantage under grazing of this flagellate, possibly related to their small size. If this also applies to other bacterivorous protozoans ingesting bacteria of similar size, this adaptation may at least partially explain why Actinobacteria become a prominent component of the bacterial community in lakes and rivers.

Phylotypes of the $\beta$-Proteobacteria found in the freshwater and brackish section of the Weser estuary fell into 3 (beta I beta II and beta IV in Fig. 7B) of the 4 clusters proposed by Glöckner et al. (2000) which comprise the great majority of typical freshwater $\beta$ Proteobacteria found in limnetic and estuarine environments. In contrast to the clusters of Actinobacteria comprising important freshwater phylotypes, the respective clusters of $\beta$-Proteobacteria also comprise cultivated strains. The phylotypes of the $\alpha$-Proteobacteria we found in the freshwater section of the Weser estuary cluster together with phylotypes of other freshwater systems (Glöckner et al. 2000, Jasper et al. 2001, Zwisler et al. 2003). It is striking though, that these phylotypes are rather closely related to or even match isolated strains such as Brevundimonas sp. (WL5-15), Novosphingobium capsulatum (formerly Sphingomonas capsulata; WL5-2), Rhodobacter capsulatus and Paracoccus kawasakiensis (WL5-5 and WL5-16 in Fig. 7A, Table 2). The latter were detected in the particle-associated bacterial fraction. These features suggest that $\alpha$-Proteobacteria found in freshwater systems and playing an important role in organic matter turnover also include isolated strains. In fact, it has been shown that on lake snow aggregates Brevundimonas diminuta and Sphingomonas sp. plus their close relatives constitute up to $60 \%$ of all $\alpha$-Proteobacteria which constitute 2 to $\sim 20 \%$ of the DAPI cell numbers (Schweitzer et al. 2001). In contrast to the $\alpha$-Proteobacteria of the freshwater section, the marine $\alpha$ Proteobacteria we found constitute exclusively phylotypes within a cluster of other phylotypes and no isolated strains. All our phylotypes, except one which was sequenced directly, matched to $100 \%$ other clones found in the North Atlantic, the North Sea and the Pacific (Beja et al. 2000, Eilers et al. 2000, Gonzalez et al. 2000).

In conclusion, our results show that the bacterial abundance in the Weser estuary during the investigation period from April to December 1999 was mainly influenced by temperature but presumably also by other factors we did not measure, such as substrate supply, growth and grazing, as indicated by the data in May 2000. The percentage of particle-associated bacteria correlated closely to the turbidity. The composition of the bacterial community appeared to be mainly controlled by the salinity and only a little by specific variables within the freshwater, brackish and marine section, even though differences occurred between the particle-associated and free-living fractions. The communities consisted of a limited number of members of the CF cluster, Actinobacteria, and $\alpha$ - and $\beta$-Proteobacteria of global significance in similar ecosystems.

Acknowledgements. We are most grateful to the crew of the RV 'Bakensand', to R. Schütte for making data available on conductivity, temperature and turbidity, to U. Fehner for counting bacteria for the FISH analysis, and to K. Adolph for $\mathrm{chl} a$ analyses. Constructive suggestions by T. Hollibaugh and 2 anonymous reviewers on an earlier version of the paper are gratefully acknowledged. This work was supported by a grant from the Deutsche Forschungsgemeinschaft (Si 360/10-1).

\section{LITERATURE CITED}

Acinas SG, Antón J, Rodríguez-Valera F (1999) Diversity of free-living and attached bacteria in offshore western Mediterranean waters as depicted by analysis of genes encoding 16S rRNA. Appl Environ Microbiol 65:514-522

Amann R, Krumholz L, Stahl DA (1990) Fluorescent-oligonucleotide probing of whole cells for determinative, phylogenetic, and environmental studies in microbiology. J Bacteriol 172:762-770

ARGE Weser (Arbeitsgemeinschaft zur Reinhaltung der Weser) (2000) Wesergütebericht 1999. Niedersächsisches Landesamt für Ökologie, Hildesheim, Germany

Beja O, Suzuki MT, Koonin EV, Aravind L and 8 others (2000) Construction and analysis of bacterial artificial chromosome libraries from a marine microbial assemblage. Environ Microbiol 2:516-529

Bell CR, Albright LJ (1981) Attached and free-floating bacteria in the Frazer River estuary, British Columbia, Canada. 
Mar Ecol Prog Ser 6:317-327

Bent EJ, Goulder R (1981) Planktonic bacteria in the Humber estuary: seasonal variation in population density and heterotrophic activity. Mar Biol 62:35-45

Bidle KD, Fletcher M (1995) Comparison of free-living and particle-associated bacterial communities in the Chesapeake Bay by stable low-molecular weight RNA analysis. Appl Environ Microbiol 61:944-952

Böckelmann U, Manz W, Neu TR, Szewzyk U (2000) Characterization of the microbial community of lotic organic aggregates ('river snow') in the Elbe River of Germany by cultivation and molecular methods. FEMS Microbiol Ecol 33:157-170

Brinkhoff T, Muyzer G (1997) Increased species diversity and extended habitat range of sulfur-oxidizing Thiomicrospira spp. Appl Environ Microbiol 63:3789-3796

Brümmer IHM, Fehr W, Wagner-Döbler I (2000) Biofilm community structure in polluted rivers: Abundance of dominant phylogenetic groups over a complete annual cycle. Appl Environ Microbiol 66:3078-3082

Bouvier TC, del Giorgio PA (2002) Compositional changes in free-living bacterial communities along a salinity gradient in 2 temperate estuaries. Limnol Oceanogr 47:453-470

Casamayor EO, Schäfer H, Bañeras L, Pedrós-Alió C, Muyzer G (2000) Identification of and spatio-temporal differences between microbial assemblages from 2 neighboring sulfurous lakes: comparison by microscopy and denaturing gradient gel electrophoresis. Appl Environ Microbiol 66: 499-508

Cottrell MT, Kirchman DL (2000) Community composition of marine bacterioplankton determined by 16S rRNA gene clone libraries and fluorescence in situ hybridization. Appl Environ Microbiol 66:5116-5122

Crump, BC, Baross JA, Simenstad CA (1998) Dominance of particle-attached bacteria in the Columbia River estuary, USA. Aquat Microb Ecol 14:7-18

Crump BC, Armbrust EV, Baross JA (1999) Phylogenetic analysis of particle-attached and free-living bacterial communities in the Columbia River, its estuary and the adjacent coastal ocean. Appl Environ Microbiol 65:3192-3204

del Giorgio PA, Bouvier TC (2002) Linking the physiological and phylogenetic succession in free-living bacterial communities along an estuarine salinity gradient. Limnol Oceanogr 47:471-486

DeLong EF, Franks DG, Alldredge AL (1993) Phylogenetic diversity of aggregate-attached vs free-living marine bacterial assemblages. Limnol Oceanogr 38:924-934

Eilers H, Pernthaler J, Glöckner FO, Amann R (2000) Culturability and in situ abundance of pelagic bacteria from the North Sea. Appl Environ Microbiol 66:3044-3051

Engel H (1995) Die Hydrologie der Weser. In: Gerken B, Schirmer M (eds) Limnologie aktuell, Vol 6. Die Weser. Gustav Fischer Verlag, Stuttgart, p 3-14

Ferrari VC, Hollibaugh JT (1999) Distribution of microbial assemblages in the central Arctic Ocean basin studied by PCR/DGGE: analysis of a large data set. Hydrobiologia 401:55-68

Findlay S, Pace ML, Lints D, Cole JJ, Caraco NF, Peierls B (1991) Weak coupling of bacterial and algal production in a heterotrophic ecosystem: the Hudson River estuary. Limnol Oceanogr 36:268-278

Giovannoni S, Rappé M (2000) Evolution, diversity, and molecular ecology of marine prokaryotes. In: Kirchman D (ed) Microbial ecology of the oceans. Wiley-Liss, New York, p $47-84$

Glöckner FO, Amann R, Alfreider A, Pernthaler J, Psenner R, Trebesius K, Schleifer KH (1996) An in situ hybridisation protocol for detection and identification of planktonic bacteria. Syst Appl Microbiol 19:403-406

Glöckner FO, Fuchs BM, R Amann R (1999) Bacterioplankton compositions of lakes and oceans: a first comparison based on fluorescence in situ hybridisation. Appl Environ Microbiol 65:3721-3726

Glöckner FO, Zaichikov E, Belkova N, Denissova L, Pernthaler J, Pernthaler A, Amann R (2000) Comparative 16S rRNA analysis of lake bacterioplankton reveals globally distributed phylogenetic clusters including an abundant group of Actinobacteria. Appl Environ Microbiol 66: 5053-5065

Gonzalez JM, Simo R, Massana R, Covert J, Casamayor E, Pedros-Alio C, Moran MA (2000) Bacterial community structure associated with a dimethylsulfonioproponiateproducing North Atlantic algal bloom. Appl Environ Microbiol 66:4237-4246

Goosen NK, van Rijswijk P, Kromkamp J, Peene J (1997) Regulation of annual variation in heterotrophic bacterial production in the Schelde estuary (SW Netherlands). Aquat Microb Ecol 12:223-232

Grabemann I, Krause G (1989) Transport processes of suspended matter derived from time series in a tidal estuary. J Geophys Res 94:14373-14379

Hollibaugh JT, Wong PS, Murrell MC (2000) Similarity of particle-associated and free-living bacterial communities in northern San Francisco Bay, California. Aquat Microb Ecol 21:103-114

Hoppe HG, Ducklow HW, Karrasch B (1993) Evidence for dependency of bacterial growth on enzymatic hydrolysis of particulate organic matter in the mesopelagic ocean. Mar Ecol Prog Ser 93:277-283

Iriberri J, Unanue M, Barcina I, Egea L (1987) Seasonal variation in population density and heterotrophic activity of attached and free-living bacteria in coastal waters. Appl Environ Microbiol 53:2308-2314

Jaspers E, Nauhaus K, Cypionka H, Overmann J (2001) Multitude and temporal variability of ecological niches as indicated by the diversity of cultivated bacterioplankton. FEMS Microb Ecol 36:153-164

Knoll S, Zwisler W, Simon M (2001) Bacterial colonization of early stages of limnetic diatom microaggregates. Aquat Microb Ecol 25:141-150

Kirchman DL, Mitchell R (1982) Contribution of particlebound bacteria to total microheterotrophic activity in 5 ponds and 2 marshes. Appl Environ Microbiol 43:200-209

Manz W, Amann R, Luwig W, Wagner M, Schleifer KH (1992) Phylogenetic oligonucleotide probes for the major subclasses of proteobacteria: problems and solutions. Syst Appl Microbiol 15:593-600

Manz W, Amann R, Ludwig W, Vancanneyt M, Schleifer KH (1996) Application of a suite of 16S rRNA-specific oligonucleotide probes designed to investigate bacteria of the phylum cytophaga-flavobacter-bacteroides in the natural environment. Microbiology 142:1097-1106

Muyzer G, De Waal EC, Uitterlinden AG (1993) Profiling of complex microbial populations by denaturing gradient gel electrophoresis analysis of polymerase chain reactionamplified genes coding for 16S rRNA. Appl Environ Microbiol 59:695-700

Muyzer G, Brinkhoff T, Nübel U, Santegoeds C, Schäfer H, Wawer C (1998) Denaturing gradient gel electrophoresis (DGGE) in microbial ecology. In: Akkermans ADL, van Elsas JD, Bruijn FJ (eds) Molecular microbial ecology manual. Kluwer Academic Publishers, Dordrecht, p 1-23

Nybakken JW (2001) Marine biology-an ecological approach, 5th edn. Benjamin Cummings, San Francisco 
Palumbo AV, Ferguson RL, Rublee PA (1984) Size of suspended bacterial cells and association of heterotrophic activity with size fractions of particles in estuarine and coastal waters. Appl Environ Microbiol 48:157-164

Pernthaler J, Posch T, Šimek K, Vrba J and 5 others (2001) Predator-specific enrichment of Actinobacteria from a cosmopolitan freshwater clade in mixed continuous culture. Appl Environ Microbiol 67:2145-2155

Phillips CJ, Smith Z, Embley TM, Prosser JI (1999) Phylogenetic differences between particle-associated and planktonic ammonia-oxidizing bacteria of the $\beta$-subdivision of the class Proteobacteria in the northwestern Mediterranean Sea. Appl Environ Microbiol 65:779-786

Rappé MS, Vergin K, Giovannoni SJ (2000) Phylogenetic comparisons of a coastal bacterioplankton community with its counterparts in open ocean and freshwater systems. FEMS Microb Ecol 33:219-232

Rheinheimer G (1991) Aquatic microbiology, 4th edn. WileyLiss Inc, New York

Riemann L, Winding A (2001) Community dynamics of freeliving and particle-associated bacterial assemblages during a freshwater phytoplankton bloom. Microb Ecol 42: $274-285$

Sambrook J, Fritsch EF, Maniatis T (1989) Molecular cloning: a laboratory manual, 2nd edn. Cold Spring Harbor Laboratory Press, Cold Spring Harbor, NY

Schuchardt B (1995) Die Schwebstoff-Dynamik in der Unterweser und ihre Bedeutung für die Gewässergüte. In: Gerken B, Schirmer M (eds) Limnologie aktuell, Vol 6. Die Weser. Gustav Fischer Verlag, Stuttgart

Schuchardt B, Busch D (1991) Seasonal and spatial variations in cell numbers of attached and free-living bacteria in the inner part of the Weser estuary. Verh Int Ver Limnol 24: $2585-2590$

Schuchardt B, Schirmer M (1991a) Intratidal variability of living and detrital seston components in the inner part of the Weser estuary: vertical exchange and advective transport. Arch Hydrobiol 121:21-41

Schuchardt B, Schirmer M (1991b) Phytoplankton maxima in the tidal freshwater reaches of 2 coastal plain estuaries.

Editorial responsibility: James Hollibaugh, Athens, Georgia, USA
Estuar Coast Shelf Sci 32:187-206

Schweitzer B, Huber I, Amann R, Ludwig W, Simon M (2001) Alpha- and beta-proteobacteria control the consumption and release of amino acids on lake snow aggregates. Appl Environ Microbiol 67:632-645

Šimek K, Pernthaler J, Weinbauer MG, Hornak K, Dolan JR, Nedoma J, Masin M, Amann R (2001) Changes in bacterial community composition and dynamics and viral mortality rates associated with enhanced flagellate grazing in a mesoeutrophic reservoir. Appl Environ Microbiol 67: $2723-2733$

Simon M (1985) Specific uptake rates of amino acids by attached and free-living bacteria in a mesotrophic lake. Appl Environ Microbiol 49:1254-1259

Simon M, Grossart HP, Schweitzer B, Ploug H (2002) Microbial ecology of organic aggregates in aquatic ecosystems. Aquat Microb Ecol 28:175-211

Smith DC, Simon M, Alldredge AL, Azam F (1992) Intense hydrolytic enzyme activity on marine aggregates and implications for rapid particle dissolution. Nature 359:139-142

Strunk O, Gross O, Reichel B, May M and 10 others (1998) ARB: a software environment for sequence data. Department of Microbiology, Technische Universität München, Munich; available at: www.arb-home.de

Urbach E, Vergin KL, Young L, Morse A, Larson GL, Giovannoni SJ (2001) Unusual bacterioplankton community structure in ultra-oligotrophic Crater Lake. Limnol Oceanogr 46:557-572

Wright RT, Coffin RB (1983) Planktonic bacteria in estuaries and coastal waters of northern Massachusetts: spatial and temporal distribution. Mar Ecol Prog Ser 11:205-216

Zwart G, Hiorns WD, Methé BA, van Agterveld MP, Huismans R, Nold SC, Zehr JP, Laanbroek HJ (1998) Nearly identical 16S rRNA sequences recovered from lakes in North America and Europe indicate the existence of clades of globally distributed freshwater bacteria. Syst Appl Microbiol 21:546-556

Zwisler W, Selje N, Simon M (2003) Seasonal patterns of the bacterioplankton community composition in a large mesotrophic lake. Aquat Microb Ecol (in press)

Submitted: July 13, 2002; Accepted: November 4, 2002 Proofs received from author(s): January 3, 2003 